\title{
Feeding Requirements of Young Cattle
}

\author{
By V. STEENSBERG \\ Department of Dairy Husbandry, Agricultural Research Laboratory, \\ Copenhagen, Denmark
}

(Received 5 May 1947)

Text-books and reports contain an abundance of information about the feeding of growing cattle. A great number of the experiments, however, covers a short part of the period of growth only, and, even though the results obtained are valuable, it must be remembered that a difference in gain in live weight in a period of a few months may very well be obliterated by an increased or decreased gain in weight in the following period.

Waters (1908) stated the following alternatives for the growth of a young animal:

(I) Steady growth from birth to maturity, as occurs with a uniform and ample food supply.

(2) Storage of fat in a period of abundant food supply to assist in tiding over a limited period of sparse food supply without serious interruption of growth.

(3) Some prolongation of the growth period. Just to what extent this is possible we cannot yet even estimate, but results already obtained indicate quite clearly that an animal, when sparsely fed through the early part of its life, may grow beyond the time when a normally fed animal is mature and has ceased to grow.

(4) A compensatory increase in the rate of growth in a period of liberal feeding following a period of low nourishment and low gain. In other words, an animal that is below the normal in size at a given age through poor nourishment, apparently has the capacity, when liberally fed, to compensate for this loss in a measure at least, by an increased rate of gain.

(5) Reduction of growth rate. Apparently the animal when kept for a long period of time on a low nutritive plane, as in the case of animals on a maintenance ration, adjusts itself to a more economical growth rate than when more liberally fed.

I have no doubt that at any rate the four first-mentioned possibilities exist; the last one which implies reduction in the requirements for maintenance, is perhaps only apparent.

It is therefore necessary that experiments on which to base norms for the feeding requirements of young dairy cattle should cover the greater part of the growth period, at any rate from birth until after the heifer's first calving, even though growth may be continued for some years more.

Among the experiments carried out throughout the greater part of the growth period, those made by Eckles \& Swett (I9I8), Isaachsen \& Ulvesli (I929), Jääskeläinen (1936), Zorn, Krallinger, Schneider \& Schott (1933), Brüggemann (r938), Schmidt \& Vogel (1929, I933), Espe, Cannon \& Hansen (1932), have been of importance. Many 
more experiments have been conducted, but in my opinion these are some of the most valuable.

In Denmark, the Laboratory for Agricultural Research conducted a series of experiments in the early I920's, the results of which have been reported by Østergaard (1934), and in 1927 a comprehensive series of experiments was put in hand under the management of the late Lars Frederiksen. These experiments are being continued. The first results were published by Frederiksen (1929), and later Steensberg (I940, I947), Eskedal \& Steensberg (I93I) and Steensberg \& Østergaard (1945) published further results of these experiments. Since all these reports are written in Danish, and as but few of them contain a very short English summary, the main features of these experiments will be described and the results and their importance discussed.

\section{EXPERIMENTAL}

'The first experiment, begun in 1927 , had for its purpose to find out how very heavy and very light food supplies might influence the growth of young animals. No fixed plan was devised for the feeding; the heavily fed animals were allowed to eat almost all that they could consume of feed materials such as skim milk and concentrates; the lightly fed animals were given sufficient for their health to be preserved, and the greater proportion of their food intake consisted of roots and hay. This experiment comprised two bulls and two heifers in each of the two groups. Hammond (1944) has mentioned this experiment in one of his publications.

The second experiment was conducted with three groups: one was lightly, one normally, and one heavily, fed. A fixed plan for the feeding was followed, the results from the first experiment having been taken into consideration. Each experimental group comprised four heifers, i.e. twelve in all. Both these experiments are reported in detail by Eskedal \& Steensberg (I93 I). In both experiments there were considerable variations in the quantities of energy foods as well as in the quantities of protein fed.

Next it was decided to find out in one series of experiments the influence of the quantity of energy, as expressed in food units (F.E.)*, upon the growth, while a second series was set up to examine the influence of the quantity of the protein used.

In the first series of experiments the quantity of S.E. for three groups was varied, one group being lightly fed, one normally, and one heavily. The protein ratio was, as far as possible, kept constant in relation to the S.E.; indeed, the absolute quantity varied in the same proportion as the quantity of S.E. So far no experiments had been carried out in which the quantity of S.E. had been varied and the quantity of protein kept constant. The quantity of protein for the lightly fed group was, however, considered sufficient for normal growth.

* The F.E. indicates the net energy and corresponds to 1650 net Cal. for fattening, the energy in I $\mathrm{kg}$. barley being used as the unit. Alternatively, the calculation may be made on the basis of the chemical analysis, the digestibility coefficients and valuation used, when the starch equivalent of the digestible nutrients is calculated. For protein the factor 0.94 and not $I \cdot 43$ is used.

The proportion between F.E. and starch equivalents (S.E.) will be

$$
\frac{\text { I F.E. }}{\text { I unit of S.E. }}=\frac{1650}{2365}=0.7 \text {, i.e. I F.E. }=0.7 \text { unit of S.E. }
$$

In the following tabulations units of s.E. calculated in the way mentioned are used. 
The experiments were carried out on animals of the three breeds common in Denmark: Red Danish Milk, Black and White Jutland and Shorthorn. There were three groups each comprising the following number of animals:

Breed

Red Danish Milk

Black and White Jutland Shorthorn

$\begin{array}{ccc}\begin{array}{c}\text { Light feeding, } \\ \text { group (B) }\end{array} & \begin{array}{c}\text { Normal feeding, Heavy feeding, } \\ \text { group (A) }\end{array} & \text { group (C) } \\ 58 & 62 & 5 \text { I } \\ 25 & 24 & 25 \\ 26 & 25 & 25 \\ \text { Total Io9 } & \text { I I I } & \text { IOI }\end{array}$

The experiment on the Red Danish Milk breed is described in detail by Steensberg (1940), while Steensberg \& Østergaard (1945) describe the experiment on the Black and White Jutland and the Shorthorn breeds.

The experiments covered $12 \frac{1}{2}$ years, the first calf of the Red Danish Milk breed being put on experimental feeding in August 1928, while the last Shorthorn heifer calved in May 1941. The distribution in groups was made at random, as the calves were born, the first calf born being included in group (A), the second in group (B), the third in group (C), and so on.

The second series of experiments, in which the influence of the protein ration was examined, did not begin until the first series had been almost completed.

The quantity of energy was kept constant in these experiments, and as far as possible on the same level as for the normal group (A) in the first series of experiments, while the quantity of protein was changed. In this case also the experiment comprised animals of the three breeds, and the following numbers were used:

\begin{tabular}{|c|c|c|c|}
\hline Breed & $\begin{array}{l}\text { Low-protein } \\
\text { ration, } \\
\text { group (B) }\end{array}$ & $\begin{array}{l}\text { Medium-protein } \\
\text { ration, } \\
\text { group (A) }\end{array}$ & $\begin{array}{l}\text { High-protein } \\
\text { ration, } \\
\text { group (C) }\end{array}$ \\
\hline \multirow{4}{*}{$\begin{array}{l}\text { Red Danish Milk } \\
\text { Black and White Jutland } \\
\text { Shorthorn }\end{array}$} & 10 & 9 & $19^{*}$ \\
\hline & 12 & I6 & 15 \\
\hline & I5 & I4 & 14 \\
\hline & Total 37 & 39 & 48 \\
\hline
\end{tabular}

* There were two groups on high-protein ration, the only difference between them being that the same quantity of skim milk was used in a different way.

These experiments are described in detail by Steensberg (1947).

In all cases the experimental feeding began when the calves were about $\mathrm{I} 6$ days old. Until that age they were fed exclusively on whole milk; as a rule they had sucked their mothers for the first $5^{-6}$ days. The experimental feeding was continued until the heifers calved for the first time, but as all experiments were conducted at the farms, Favrholm and Trollesminde, attached to the Laboratory, it was also possible to follow the growth of some of the animals after the first calving.

Throughout the winter periods the animals were in the byres and were fed individually. Calves $3-10$ months old were put out to grass in the daytime during the summer; at night they were housed and got additional fodder in varying quantities, most for the heavily fed groups and least for the lightly fed groups. All calves grazed in the same grass field. Heifers over 10 months got only grass and grazed on the same 
pasture. Therefore the feeding conditions were identical for these animals during the 6 summer months.

As to feeding-stuffs, roughages and cereals were grown on the farm. The concentrates consisted of cereals and linseed cake only, when skim milk was. used. For calves and heifers, which did not get milk, a concentrate mixture was used which, in view of the importance of the biological value of the proteins, contained at least four, and frequently six or seven, different sorts of oilcake, meat-meal, fish-meal and cereals.

The animals were weighed and measured once monthly in the Ist year of their lives. During the and year they were also weighed and measured once monthly during the winter time, but less frequently when they were put out on pasture.

When the animals were put on pasture they were weighed on 3 consecutive days. The autumn weighing, when the animals were taken off the land, was not undertaken until they had been on winter feed for about ro days, since the different rumen content of winter feed and of grass might affect the weight. The quantities of grass consumed were calculated according to the norms used by the Society of Scandinavian Agricultural Scientists (Steensberg, 1935).

\section{RESULTS}

\section{Variation in the intake of energy foods}

In the experiments with varying quantities of energy foods, the animals were fed during the winter time according to the plan shown in Table I, which also shows the quantities of S.E. consumed, calculated on the basis of the quantities of fodder weighed out and the chemical analysis.

The animals in the heavily fed group (C) got almost as much as they could consume, while the lightly fed group (B) got considerably less than they could have consumed. However, they did not show symptoms of real hunger, apparently because their fodder took up almost the same space in the rumen as that of the other groups. The animals in group (C) were in a nearly 'finished' condition all the time. Animals in group (A) in the first few months were in average condition, while later they were in better than average condition. Those in group (B) were rather lean. Plate I shows typical animals about 5 months old.

The total quantities of fodder consumed during the course of the experiments are shown in Table 2.

The lightly fed group was given only small quantities of whole milk and skim milk and very little concentrates. The normal group was given medium quantities, and the heavily fed group large quantities, of these feeding-stuffs. The quantities of hay consumed were very similar for all groups, and the quantities of roots and straw consumed did not differ much either.

In terms of s.E., the (B) group was given in milk and concentrates about $10 \%$, the (A) group about $20 \%$, and the (C) group about $30 \%$, of the food intake. About $40-48 \%$ of the intake consisted of roots, hay, and straw, while the rest, that is $45 \%$ for the (B) group, $35 \%$ for the (A) group, and $30 \%$ for the (C) group, consisted of grass. 


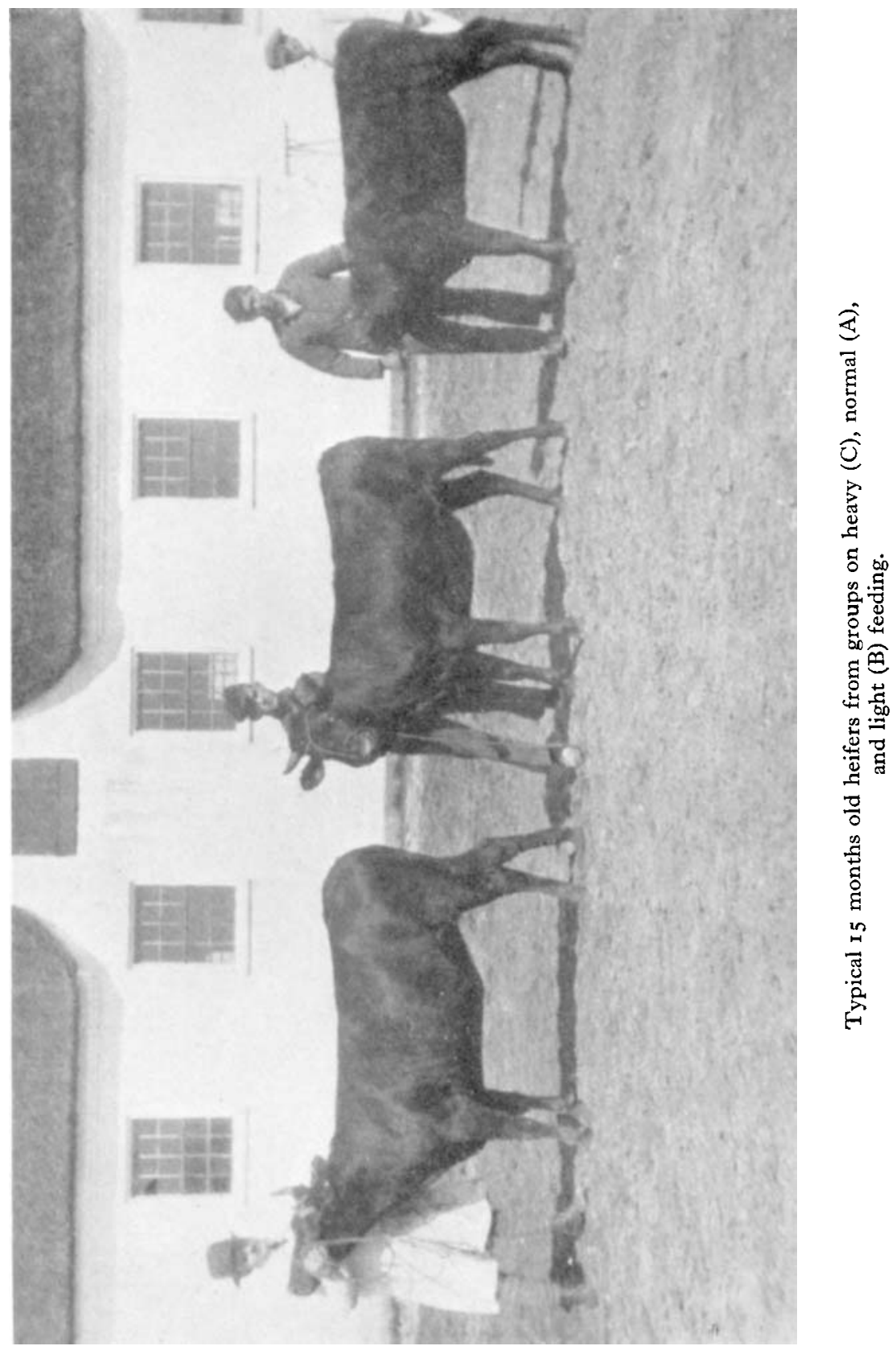

V. STEENSBERG. FEEDING REQUIREMENTS OF YOUNG STOCK 


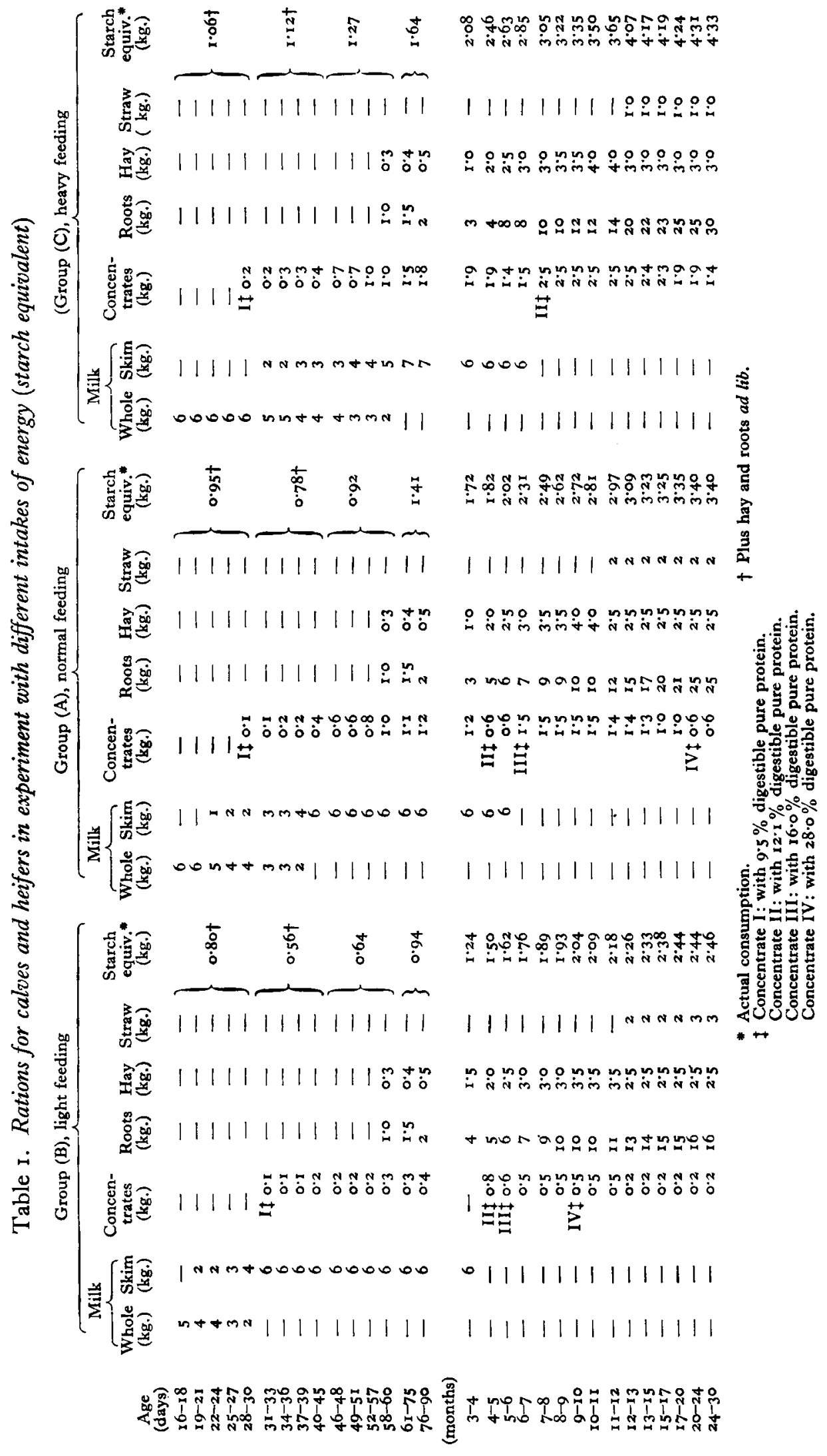




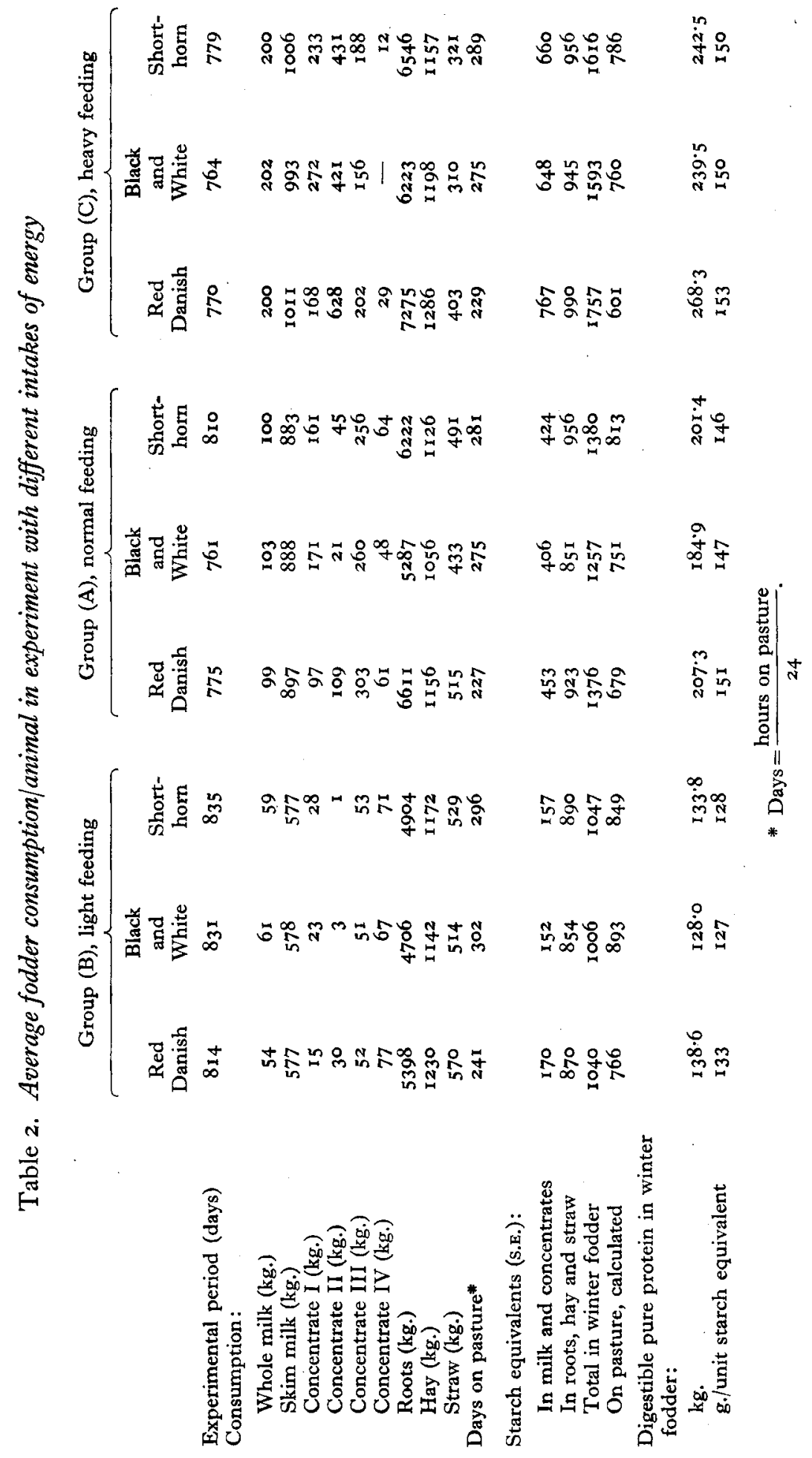


Table 3 gives the live weights during the experimental period.

There is a considerable difference between the differently fed groups, but within a particular group there is only a slight difference between the three breeds. That is to say, these three breeds grow alike under uniform feeding conditions.

Table 3. Average live weights of the different groups and breeds in the course of the experiment with different intakes of energy

Group (B), light feeding Group (A), normal feeding

\begin{tabular}{|c|c|c|c|c|c|c|c|c|c|}
\hline $\begin{array}{c}\text { Age } \\
\text { (months) }\end{array}$ & $\begin{array}{c}\text { Red } \\
\text { Danish }\end{array}$ & $\begin{array}{l}\text { Black } \\
\text { and } \\
\text { White }\end{array}$ & $\begin{array}{l}\text { Short- } \\
\text { horn }\end{array}$ & $\begin{array}{c}\text { Red } \\
\text { Danish }\end{array}$ & $\begin{array}{l}\text { Black } \\
\text { and } \\
\text { White }\end{array}$ & $\begin{array}{l}\text { Short- } \\
\text { horn }\end{array}$ & $\begin{array}{c}\text { Red } \\
\text { Danish }\end{array}$ & $\begin{array}{l}\text { Black } \\
\text { and } \\
\text { White }\end{array}$ & $\begin{array}{l}\text { Short- } \\
\text { horn }\end{array}$ \\
\hline $\begin{array}{c}\text { At birth } \\
\frac{1}{2} \\
x^{\frac{1}{2}} \\
2 \frac{1}{2} \\
3 \frac{1}{2}\end{array}$ & $\begin{array}{l}39 \cdot 0 \\
46 \cdot 5 \\
61 \cdot 0 \\
76 \cdot 2 \\
92 \cdot 4\end{array}$ & $\begin{array}{l}38 \cdot 3 \\
48 \cdot 1 \\
61 \cdot 3 \\
77 \cdot 2 \\
94 \cdot 7\end{array}$ & $\begin{array}{l}34 \cdot 5 \\
44 \cdot 2 \\
54 \cdot 5 \\
67 \cdot 8 \\
84 \cdot 8\end{array}$ & $\begin{array}{r}39 \cdot 0 \\
46 \cdot 3 \\
63 \cdot 9 \\
83 \cdot 0 \\
\text { IOr.5 }\end{array}$ & $\begin{array}{l}37 \cdot 3 \\
46 \cdot 8 \\
61 \cdot 8 \\
78 \cdot 8 \\
98 \cdot 7\end{array}$ & $\begin{array}{l}35 \cdot 4 \\
44 \cdot 3 \\
59 \cdot 8 \\
76 \cdot 8 \\
94 \cdot 6\end{array}$ & $\begin{array}{r}40 \cdot 0 \\
47 \cdot 6 \\
67 \cdot 4 \\
89 \cdot 0 \\
108 \cdot 9\end{array}$ & $\begin{array}{r}38 \cdot 2 \\
48 \cdot 3 \\
65 \cdot 6 \\
87 \cdot 7 \\
109 \cdot 4\end{array}$ & $\begin{array}{l}34 \cdot 7 \\
44 \cdot 2 \\
62 \cdot 6 \\
80 \cdot 2 \\
99 \cdot 6\end{array}$ \\
\hline $4 \frac{1}{2}$ & 103.4 & II 1.5 & $97 \cdot 2$ & II $90^{\circ}$ & 119.6 & I 5.9 & $\times 27.9$ & $132 \cdot 5$ & 120.7 \\
\hline $5^{\frac{1}{2}}$ & 115.8 & 124.3 & $109 \cdot 7$ & 140.2 & 139.4 & 135.4 & 151.8 & $r_{54} \cdot 6$ & $143^{\circ} 2$ \\
\hline $6 \frac{1}{2}$ & $128 \cdot I$ & I 37.8 & $121 \cdot 5$ & $\times 58.3$ & 工 59.8 & $15 \times \cdot 5$ & $17 x \cdot 9$ & 178.4 & 167.2 \\
\hline $7 \frac{1}{2}$ & $14 r^{r} \cdot 8$ & 148.8 & 134.3 & $175^{.8}$ & 176.7 & 169.0 & $x 93.2$ & $198 \cdot I$ & 185.7 \\
\hline $8 \frac{1}{2}$ & $156 \cdot 1$ & $162 \cdot 0$ & 148.0 & I94. I & $193^{\circ} 0$ & 185.7 & $213 \cdot 1$ & 213.7 & $203 \cdot 6$ \\
\hline $9 \frac{1}{2}$ & $170 \cdot 4$ & $176 \cdot 2$ & 160.0 & $211 \cdot 8$ & 210.5 & 198.6 & $23 \times \cdot 9$ & $2355^{\circ}$ & $220 \cdot 2$ \\
\hline $10 \frac{1}{2}$ & 186.3 & $189 \cdot 4$ & 178.3 & $227 \cdot 2$ & 224.9 & $2 \pi 4.5$ & 249.9 & $251 \cdot 1$ & $238 \cdot 2$ \\
\hline $\operatorname{II} \frac{1}{2}$ & $200 \cdot 3$ & $203 \cdot 5$ & $\begin{array}{r}r 93.9 \\
\end{array}$ & $242 \cdot I$ & 239.8 & 230.8 & 268.0 & $265 \cdot 8$ & $256 \cdot 1$ \\
\hline $12 \frac{4}{2}$ & 2153 & $217 \cdot 8$ & $209 \cdot 2$ & 259.9 & $256 \cdot 3$ & $247 \cdot 6$ & $289 \cdot 2$ & $285 \cdot 2$ & $272 \% 0$ \\
\hline $13 \frac{1}{2}$ & $228 \cdot I$ & $23 I \cdot I$ & $224 \cdot 2$ & $275 \cdot 9$ & 273.4 & $264 \cdot 6$ & 308.8 & $302 \cdot 6$ & 290.9 \\
\hline $14 \frac{1}{2}$ & $242 \cdot 1$ & $242 \cdot 6$ & 237.3 & $289 \cdot 3$ & $292 \cdot 0$ & $28 I \cdot 5$ & $325 \cdot 3$ & $321 \cdot 7$ & 308.0 \\
\hline $15 \frac{1}{2}$ & 255.9 & $257 \cdot 9$ & 250.3 & $302 \cdot 8$ & $308 \cdot 9$ & $299^{\circ} 0$ & 335.7 & $343 \cdot 2$ & $326 \cdot 6$ \\
\hline $16 \frac{1}{2}$ & $27 \times 3$ & $271 \cdot 9$ & $267 \cdot 3$ & 316.3 & 323.4 & $3^{15} \cdot 7$ & 350.7 & $35^{8 \cdot 8}$ & $342 \cdot 5$ \\
\hline $17 \frac{1}{2}$ & $285 \cdot 3$ & $285 \cdot 6$ & 280.5 & 328.7 & 335.2 & 330.7 & $361 \cdot 9$ & $373 \cdot 8$ & $357 \cdot 2$ \\
\hline $18 \frac{1}{2}$ & $301 \cdot 2$ & $302 \cdot 2$ & 297.4 & $344^{\circ} \circ$ & 347.7 & $345 \cdot 3$ & $37 \times \cdot 7$ & 387.8 & 372.8 \\
\hline $1.9 \frac{1}{2}$ & $316 \cdot 3$ & 316.5 & $3 \mathrm{r}_{3} \cdot 4$ & 358.9 & $362 \cdot 3$ & 359.0 & $383_{3} \cdot 8$ & 400.5 & $3^{86 \cdot 6}$ \\
\hline $20 \frac{1}{2}$ & 330.6 & $332 \cdot 2$ & $327 \cdot 2$ & $375 \cdot 4$ & $378 \cdot 7$ & $374 \cdot 2$ & 397.8 & 410.1 & $399 \cdot I$ \\
\hline $21 \frac{1}{2}$ & 343.5 & $346 \cdot 2$ & $34 I^{1} \cdot 6$ & 393.2 & $393^{\circ} \circ$ & 387.5 & 414.4 & $428 \cdot 3$ & $413 \cdot 2$ \\
\hline $22 \frac{1}{2}$ & $35^{6} \cdot 9$ & $360 \cdot I$ & $354: 3$ & $406 \cdot I$ & $408 \cdot 2$ & $402 \cdot 6$ & $433 \cdot 3$ & 447.5 & $429 \cdot 5$ \\
\hline $23^{\frac{1}{2}}$ & $370 \cdot 8$ & $38 x \cdot 5$ & $367 \cdot 3$ & $424 \cdot 7$ & $422 \cdot I$ & 417.9 & 452.8 & $466 \cdot 4$ & $445^{\circ} \circ$ \\
\hline fter calving & $372 \cdot 2$ & $392 \cdot 7$ & $39 \times \cdot 3$ & $405 \cdot 3$ & $403 \cdot x$ & $432 \cdot 0$ & $439^{\prime} x$ & $44 r \cdot 8$ & $441 \cdot 5$ \\
\hline
\end{tabular}

If the whole experimental period is taken we find the following daily gain in g.:

\section{Breed}

Red Danish Milk

Black and White Jutland

Shorthorn
Light feeding, Normal feeding, Heavy feeding, group (B) group (A) group (C)

$\begin{array}{lll}400 & 463 & 508 \\ 415 & 468 & 515 \\ 416 & 479 & 510\end{array}$

The aim was to make all animals calve simultaneously at an age of $2 \frac{1}{4}$ years, but this was not possible in all cases. Some calved earlier, and some were substantially older before they calved. The age at calving as well as the weight immediately after this were as follows:

Light feeding group (B)

$$
\text { Breed }
$$

Red Danish Milk

Black and White Jutland

Shorthorn

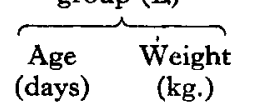

$\begin{array}{ll}830 & 372 \\ 847 & 393 \\ 852 & 391\end{array}$

Normal feeding, group (A)

$\begin{array}{cc}\begin{array}{c}\text { Age } \\ \text { (days) }\end{array} & \begin{array}{c}\text { Weight } \\ \text { (kg.) }\end{array} \\ 791 & 405 \\ 778 & 403 \\ 827 & 432\end{array}$

Heavy feeding, group (C)

$\begin{array}{cc}\begin{array}{c}\text { Age } \\ \text { (days) }\end{array} & \begin{array}{c}\text { Weight } \\ \text { (kg.) }\end{array} \\ 786 & 439 \\ 78 \mathrm{I} & 442 \\ 796 & 442\end{array}$


The intensity of feeding, and to some extent the age, affected the size of the heifers at first calving.

After the first calving the heifers were included in the milking herd, where they were fed according to the Danish standard norm (Frederiksen \& Østergaard, I93I), so that all of them were given a maintenance ration corresponding to $500 \mathrm{~kg}$. live weight. By this the small (B) animals gained a slight advantage. As mentioned above, it was possible to follow a large number of the cows until third calving, and Table 4 indicates the age and weight of these animals.

With the Red Danish and Black and White Jutland breeds there was only a slight difference in the weight of the three groups after the third calving. The heavily fed animals weighed a few kg. more than the normally or lightly fed ones. With the Shorthorns there was a little difference; here the average weights of the heavily and the normally fed animals were almost the same, but the lightly fed animals weighed somewhat less.

More detailed examinations were made with the Red Danish Milk breed in order to ascertain how the animals gained weight during the period between the first and third calving, and it was found that the lightly fed cows showed a greater gain in weight than the other animals during the grazing period. It will be seen below that the same was the case during the actual experimental period. The examination showed the following gains for cows during the summer:

$\begin{array}{lccc}\text { Group } & \begin{array}{c}\text { Between first } \\ \text { and second } \\ \text { calving } \\ \text { (kg.) }\end{array} & \begin{array}{c}\text { Between second } \\ \text { and third } \\ \text { calving } \\ \text { (kg.) }\end{array} \\ \text { (B) Lightly fed } & 4 \text { I } & 34 \\ \text { (A) Normally fed } & 2 \text { I } & 3 \text { I } \\ \text { (C) Heavily fed } & \text { I5 } & \text { I5 }\end{array}$

On the whole, the experiment proved that the difference in weight due to the different feeding systems has a tendency to disappear during the continued growth of the cows, and that this levelling up takes place particularly in summer, when the animals obtain abundant and uniform food.

Special calculations were made in an endeavour to clear up the question of the food consumption $/ \mathrm{kg}$. gain in weight. This computation only covered parts of the winter period, as the food consumption in summer was calculated only indirectly and was inapplicable in this connexion.

An attempt was made to divide total food consumption into maintenance food and production food. The maintenance requirements were estimated from the live weight $(W)$ on the basis of a requirement of $2 \cdot 67$ S.E. $/ 500 \mathrm{~kg}$. live weight according to the formula

Maintenance requirements $=2 \cdot 67(W / 500)^{\frac{5}{5}}$ S.E.

The estimated amount of food available for production was obtained by difference. Table 5 shows the results of a calculation of the efficiency of food utilization.

It will be seen that the feed consumption/kg. gain increases markedly with increasing age, whether total S.E. or production S.E. is used in the calculation. Further, the table 


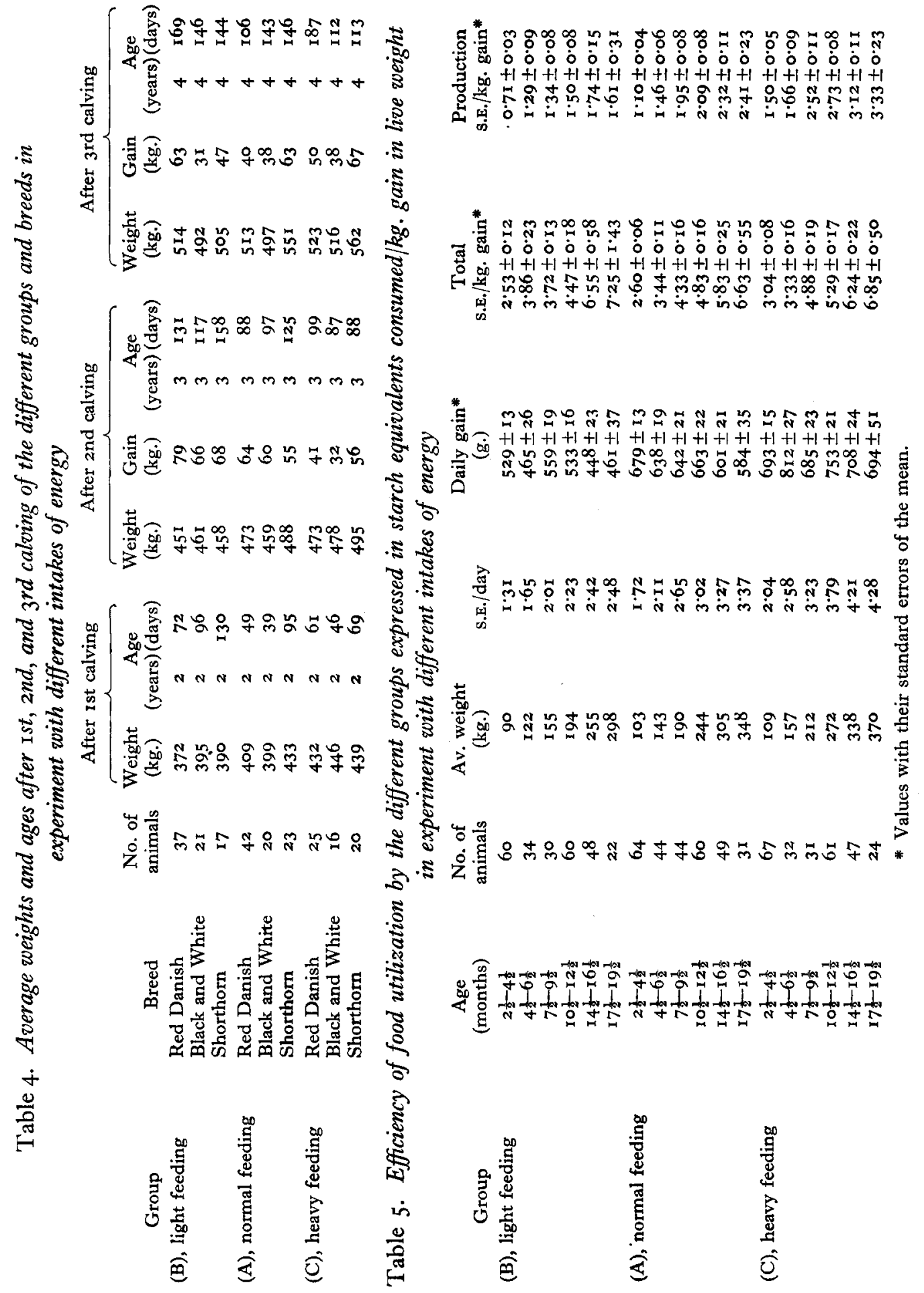


indicates only little difference in total consumption $/ \mathrm{kg}$. gain between groups of the same age, while the consumption for production $/ \mathrm{kg}$. gain is much greater for heavily fed than for normally or lightly fed animals. Measured in production S.E., I kg. gain in live weight is consequently cheaper at equal weights in the case of the lightly fed animals than for the heavily and normally fed. The reason why differences in production requirements $/ \mathrm{kg}$. gain do not result in differences in total consumption $/ \mathrm{kg}$. gain is that it takes the lightly fed animals a longer time than the other two groups to gain I kg., and that consequently their maintenance consumption $/ \mathrm{kg}$. gain is greater than for the heavily and normally fed animals; the effect of the small consumption for production $/ \mathrm{kg}$. gain of the lightly fed group is thus neutralized.

The lightly fed animals showed a considerable gain in weight in summer, as their feeding was almost the same as that of the other animals, except during the first summer when additional fodder was given besides grass.

This gain is apparent from the following survey of the partition of the total gains in weight during the winter and the summer periods:

(B) Lightly fed

Group and breed

Red Danish Milk

Black and White Jutland

Shorthorn

(A) Normally fed

Red Danish Milk

Black and White Jutland

Shorthorn

(C) Heavily fed

Red Danish Milk

Black and White Jutland

Shorthorn
Gain in weight

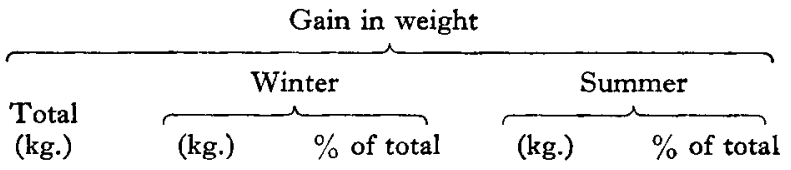

326

348

344

180

208

201

55
60
58

146

140

$\times 43$

45

40

42

244

239

257

\section{8 \\ 67}

66

$\begin{array}{ll}\text { I I } 4 & 32 \\ \text { I } 8 & 33 \\ \text { I } 31 & 3^{4}\end{array}$

2,82

276

283

72
70
70

70

$\begin{array}{ll}\text { IIO } & 28 \\ \text { II5 } & 30 \\ \text { II } & 30\end{array}$

In order to ascertain the cause of the observed difference in gain on pasture, a special experiment was carried out at the beginning of the summer period of 1932 with fifteen typical heifers varying from 12 to 18 months of age.

These heifers were kept in the shed at feeding times, and each animal was given an opportunity to eat unlimited quantities of fresh grass, clover or lucerne; for the rest of the time they were enclosed in gravelled yards. The fodder was accurately weighed, and samples were taken for chemical analysis. The experiment covered the time $20 \cdot \mathrm{May}-13$ October, and during this period the following average quantities were consumed/animal daily:

(B) Lightly fed: $29.4 \mathrm{~kg}$. grass with $6.81 \mathrm{~kg}$. dry matter

(A) Normally fed: $28.8 \mathrm{~kg}$. grass with $6.65 \mathrm{~kg}$. dry matter

(C) Heavily fed: $29.2 \mathrm{~kg}$. grass with $6.76 \mathrm{~kg}$. dry matter

Thus there was a very slight variation in the quantity of fodder consumed, the food value of which was calculated as $3 \cdot 21,3^{\cdot} \cdot 14$ and $3 \cdot 19$ S.E. for the (B), (A) and (C) animals respectively. 
At the same time the heifers showed the following daily gains in weight:

(B) Lightly fed: $599 \pm 44^{*} \mathrm{~g}$.

(A) Normally fed: $485 \pm 39^{*} \mathrm{~g}$.

(C) Heavily fed: $403 \pm 39^{*} \mathrm{~g}$.

* Standard error of the mean.

The lightly fed gained almost $200 \mathrm{~g}$. more on the same quantity of fodder than the heavily fed animals. The explanation must lie, essentially, in the different requirements for maintenance. The following table shows the average weights at the beginning and at the end of the experiment and the calculated partition of the fodder into maintenance and production food:

\begin{tabular}{|c|c|c|c|c|c|c|}
\hline \multirow{2}{*}{\multicolumn{2}{|c|}{ Group }} & \multicolumn{2}{|c|}{ Weight } & \multirow[b]{2}{*}{$\begin{array}{l}\text { Maintenance } \\
\text { (s.E. daily) }\end{array}$} & \multirow[b]{2}{*}{$\begin{array}{l}\text { Production } \\
\text { (s.E. daily) }\end{array}$} & \multirow[b]{2}{*}{$\begin{array}{l}\text { Production } \\
\text { (s.E./kg. gain } \\
\text { in weight) }\end{array}$} \\
\hline & & $\begin{array}{c}\text { At beginning* } \\
\text { of experiment } \\
\text { (kg.) }\end{array}$ & $\begin{array}{l}\text { At end } \dagger \\
\text { of experiment } \\
(\mathrm{kg} .)\end{array}$ & & & \\
\hline (B) & Lightly fed & 240 & 336 & $x \cdot 89$ & $I \cdot 32$ & $2 \cdot 25$ \\
\hline (A) & Normally fed & 300 & 377 & $2 \cdot 10$ & $\mathrm{I} \cdot \mathrm{O}_{4}$ & $2 \cdot 20$ \\
\hline (C) & Heavily fed & 346 & $4 I I$ & $2 \cdot 24$ & 0.95 & $2 \cdot 42$ \\
\hline
\end{tabular}

* Average weight for 3 consecutive days $17-19$ May on winter fodder.

+ Average weight for 3 consecutive days 24-26 October on winter fodder.

The big (C) heifers, which during the winter were heavily fed, had considerably larger maintenance requirements than the (A) or (B) heifers so that their gains were small. Besides, there was an indication that the gains in live weight of these animals cost more $/ \mathrm{kg}$. than for the others; this affords an explanation of the findings.

To the practical farmer the investigation shows that it does not pay him to feed heavily in winter I2-r 5 months old heifers, if he has good grazing at his disposal for the summer feeding. A somewhat lighter winter feeding will give the best chances for the most economical utilization of the summer grazing.

\section{Variation in the intake of proteins}

The series of experiments with rations of varying protein content was started in the autumn of 1933 with animals of Red Danish Milk breed. With these animals the first experiment was completed in the spring of I939, but another experiment with animals of the Black and White Jutland and Shorthorn breeds was started in the autumn of $193^{8}$, and the last heifer of this experiment calved in the spring of 1946 , so that this series of experiments also covered about $12 \frac{1}{2}$ years.

Table 6 outlines the feeding plan in the first experiment (Ka.4). It should be observed here that the quantities are given in terms of digestible pure protein. The quantities of digestible crude protein would be $15-20 \%$ higher for the calves during the time when milk was used; later on it is necessary to reckon with $20-25 \%$ higher quantities of crude protein.

It will be seen that the skim milk for groups $(A)$ and $(C)$ was distributed over the whole first year of life; while the same total quantity of milk was used for group $\left(\mathrm{C}_{2}\right)$ as for group (C), it was given in the course of the first 8 months of life. 


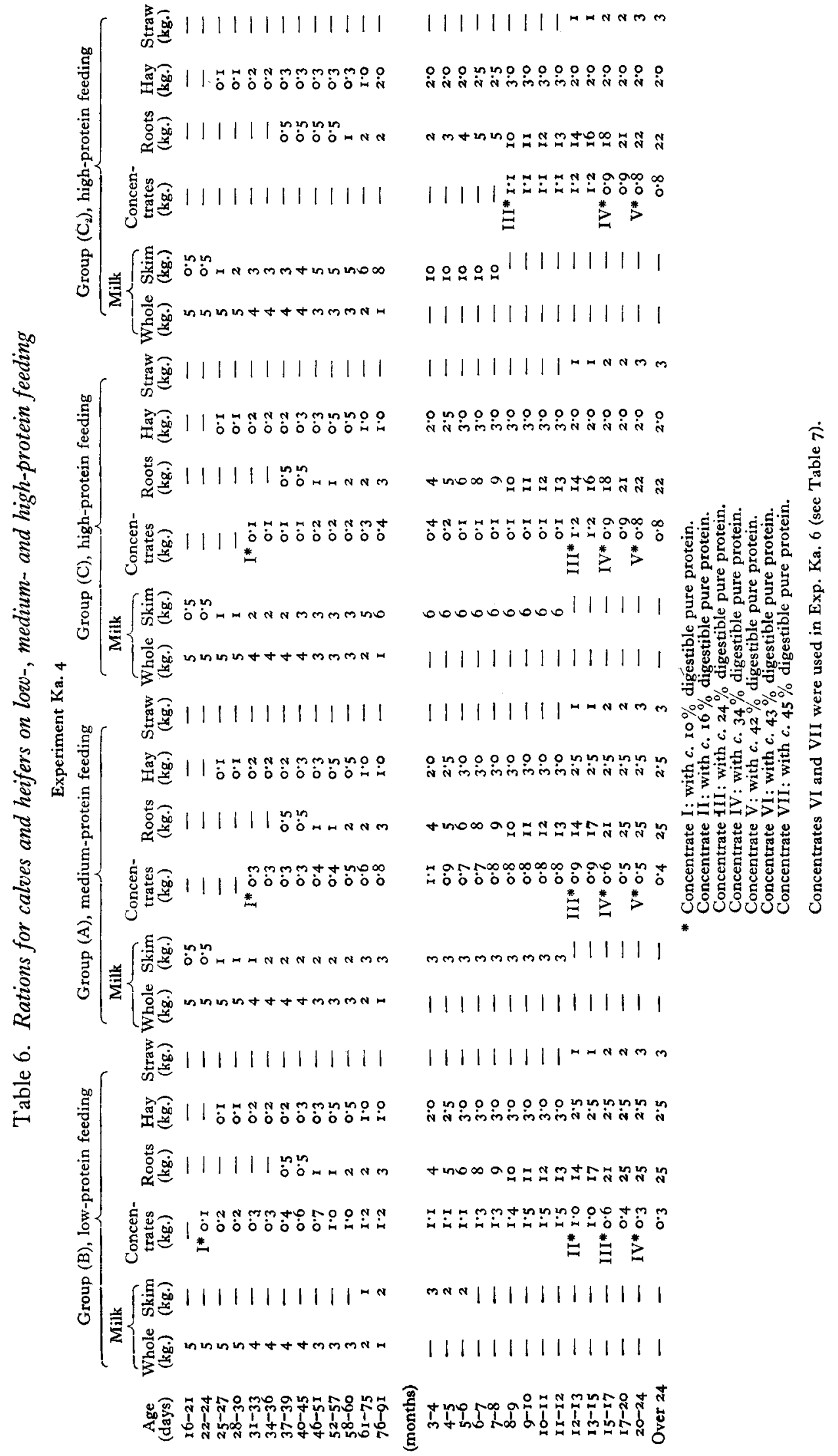


The plan for the second experiment (Ka.6) differed only slightly from the plan for Ka.4. The normal group of Ka. 6 was given almost the same quantities as the lowprotein group of $\mathrm{Ka} .4$, while the low-protein group of Ka. 6 was given considerably less. The s.E. of the rations were a little higher in the latter than in the former experiment; they corresponded to those of rations used for the normal group in the experiments on the energy requirements (see Tables $I$ and 8).

Table 7 gives the total fodder consumed in experiments Ka. 4 and Ka. 6.

After the experiments had been completed, it was possible on the basis of weight of fodder and chemical analysis to calculate the consumption of protein and of S.E. of the animals in the seven experimental groups. The results are to be found in Table 8.

According to the plan, the groups were given almost the same amount of s.E., and group (B) of the second experiment (Ka.6) was given the lowest protein ration. It was only in exceptional cases that this group received more than $300 \mathrm{~g}$. digestible pure protein daily, and up to the age of 2 years the protein ration only amounted to about $\mathrm{r}_{3} \%$ of the total quantity of net energy. According to Møllgaard's (194I $a$ ) method of calculation the $K$-value was 0.13 . However, the amount of protein/s.E. decreased so fast that it was $80-90 \mathrm{~g}$. at the age of I year. In this case the protein only amounted to $8 \%$ of the total net energy, that is to say the $K$-value was slightly below $0 \cdot 1$, and corresponded to the ration which Mellgaard (194I $b$ ) as well as Frederiksen (1930) consider as adequate for maintenance.

The weight figures in Table 9 show the influence of the different protein rations on the growth of the animals.

With the Red Danish Milk breed, groups (B), (A) and (C) follow each other rather closely, whereas group $\left(C_{2}\right)$ is behind after 8 or 9 months' growth. The cause of this will be mentioned later on. It will be seen that with the Black and White Jutland breed group (C) shows the greatest gain in weight; however, there is but little difference between this group and group (A), while the gain of group (B) is considerably lower; the same is true of the Shorthorn breed. It can be said with certainty that the lowprotein ration of group (B) in the second experiment (Ka.6) caused a considerable decrease in the gain in weight.

The protein rations given to group (B) in the first experiment, and to group (A) in the second experiment seem to have been sufficient for normal gain in weight.

Such a high-protein ration as was used for group (C) does not seem to be necessary.

The fact that the heifers of group $\left(\mathrm{C}_{2}\right)$ in the first experiment, after the age of 8 or 9 months, showed considerably smaller gains in weight than the heifers of the other groups is most probably due to the change from feeding with large quantities of skim milk. From the beginning of the experiment till the age of 8 months (when skim milk feeding for group $\left(C_{2}\right)$ was stopped) the daily gains in weight for the four groups were as follows:

(B) Low protein : $640 \pm 20 * \mathrm{~g}$

(A) Medium protein: $585 \pm 20^{*} \mathrm{~g}$.

(C) High protein : $647 \pm 19^{*} \mathrm{~g}$.

$\left(C_{2}\right)$ High protein: $694 \pm \mathrm{r} 7^{*} \mathrm{~g}$.

* Standard error of the mean. 


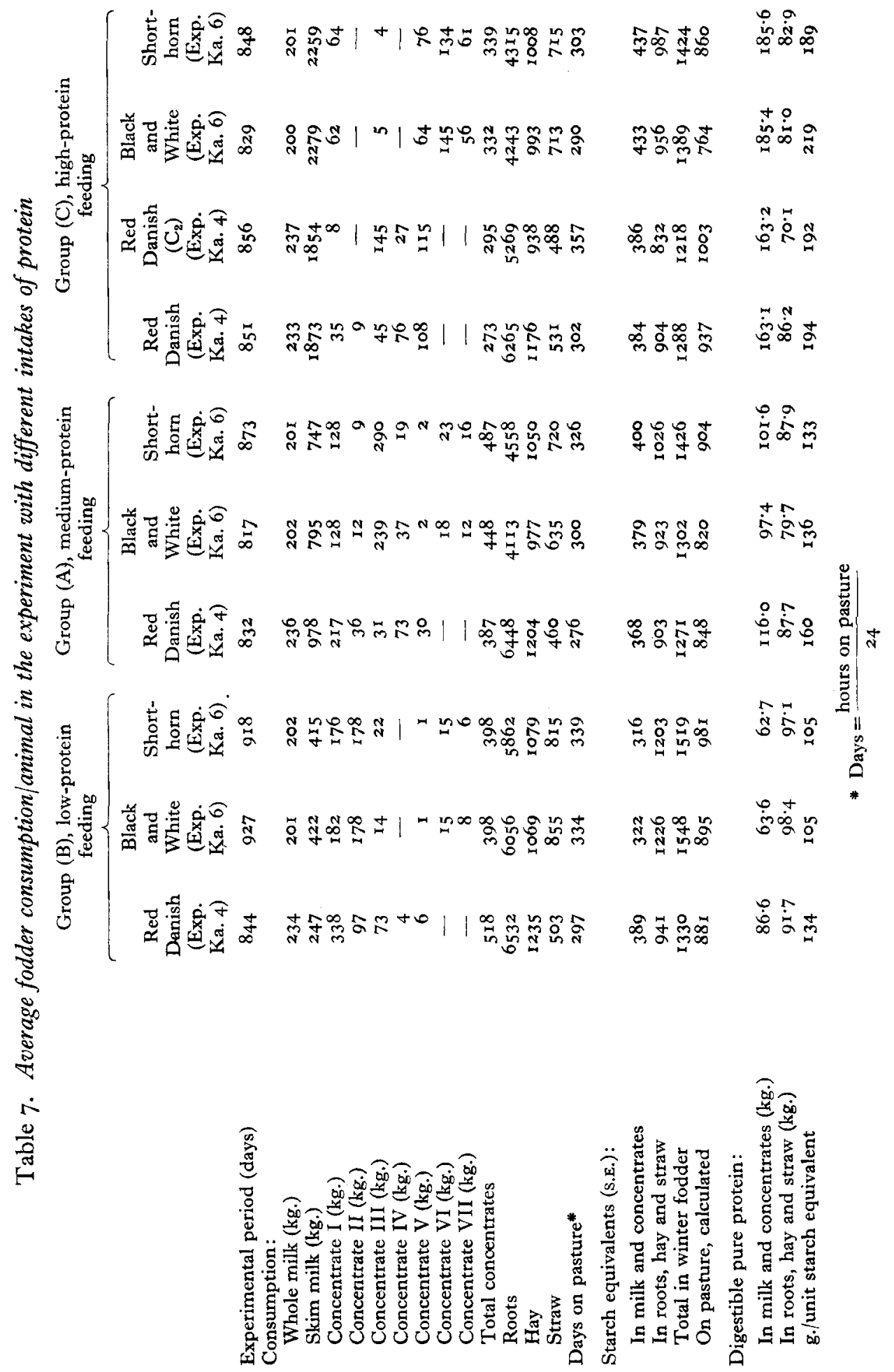




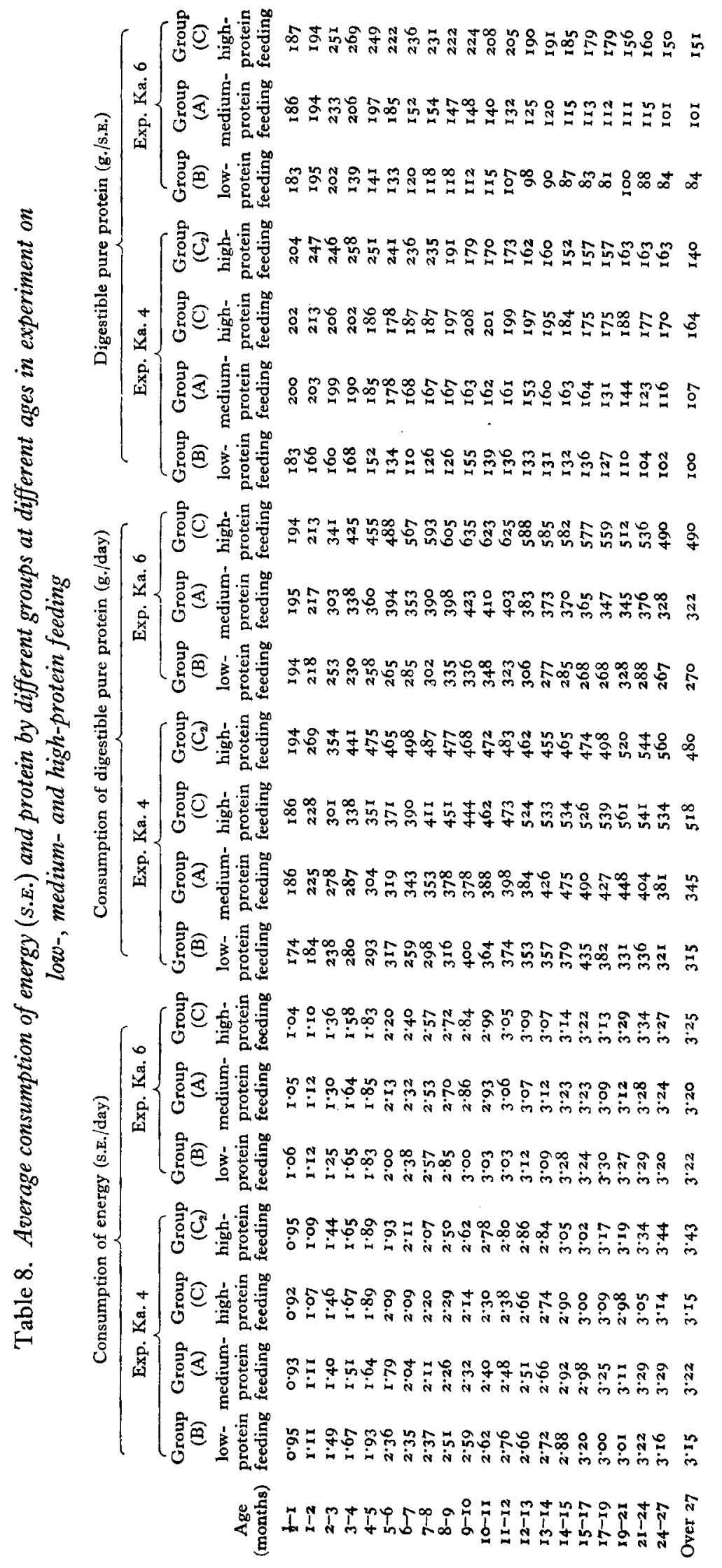




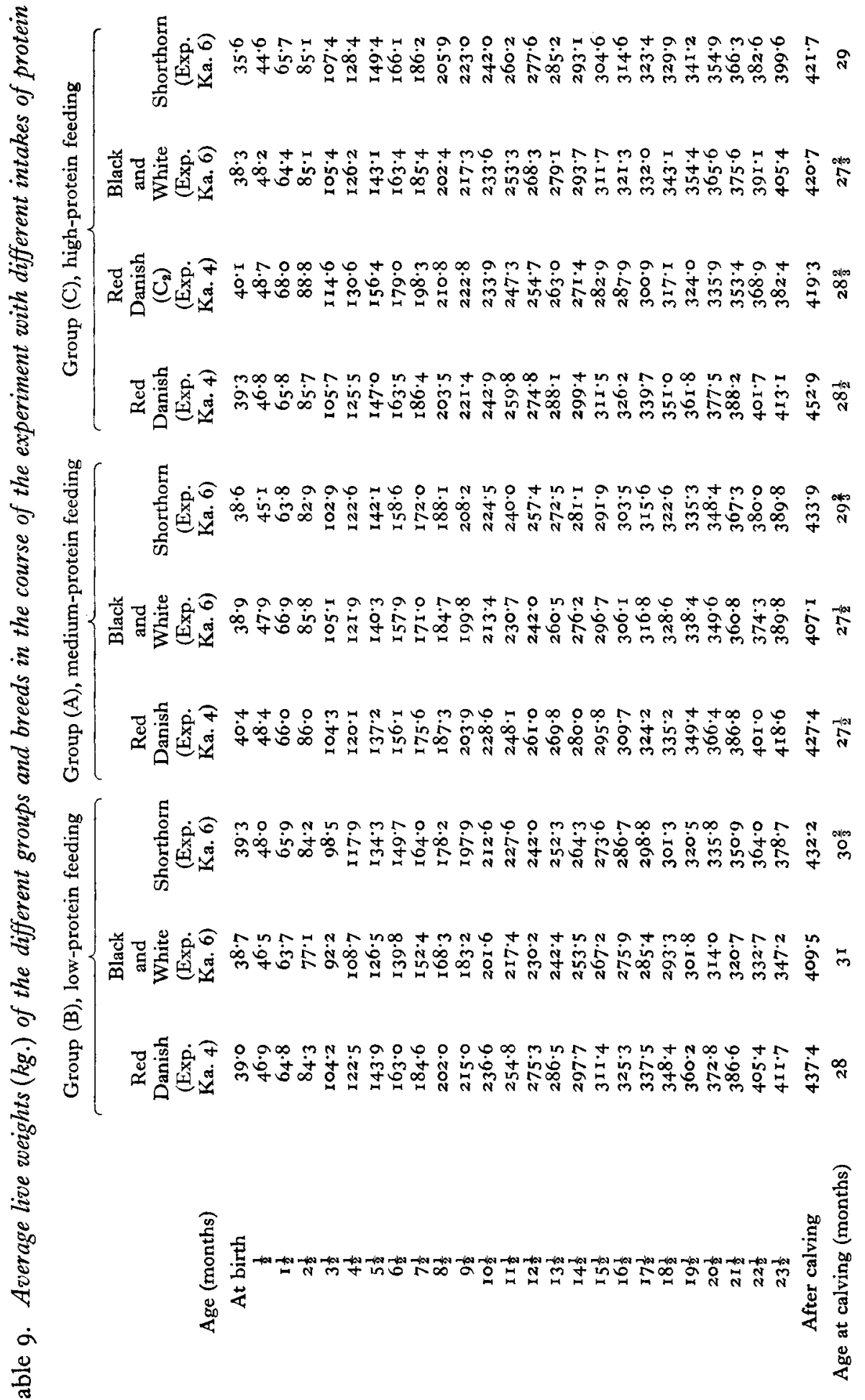


In this period group $\left(\mathrm{C}_{2}\right)$ gained most, but in the following 3 or 4 months the results were quite different, the daily gains being:
(B) Low protein: $\quad 578 \pm 56^{*} \mathrm{~g}$.
(C) High protein: $618 \pm 50^{*} \mathrm{~g}$.
(A) Medium protein: $595 \pm 29^{*} \mathrm{~g}$.
$\left(C_{2}\right)$ High protein : $447 \pm 64^{*} \mathrm{~g}$.

* Standard error of the mean.

Most of the heifers of group $\left(\mathrm{C}_{2}\right)$ were about 7 or 8 months old, when they were put on pasture. The transition from a very concentrated fodder with much milk to grass with a small additional amount of concentrates and hay retarded the growth so much that it was not possible for them to make up for the loss during the remaining part of the experiment. Consequently it is not advisable to feed as much skim milk as was given to group $\left(\mathrm{C}_{2}\right)$. It is preferable to spread a smaller daily quantity over the whole first year of life, as was done with group (C).

Some interesting details may also be pointed out in the second experiment (Ka.6). In winter the daily ration and live-weight gain of calves of the age of about 7 months at the beginning of the period were as follows:

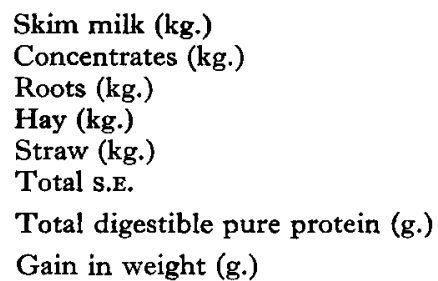

$\begin{array}{ccc}\text { Group (B) } & \text { Group (A) } & \text { Group (C) } \\ 0 & 0 & 4 \cdot 6 \\ 1 \cdot 0 & 1 \cdot 3 & 0.5 \\ 10 \cdot 0 & 9 \cdot 0 & 7 \cdot 0 \\ 2 \cdot 5 & 2 \cdot 5 & 2 \cdot 5 \\ 1 \cdot 1 & 1 \cdot 2 & 0 \cdot 6 \\ 2 \cdot 98 & 2 \cdot 86 & 2 \cdot 81 \\ 304 & 381 & 593 \\ 564 \pm 15^{*} & 622 \pm 18^{*} & 668 \pm 27^{*}\end{array}$

* Standard error of the mean.

For the heifers which were about I I months old at the beginning of the winter, the daily amounts of fodder and the daily live-weight gains were as follows:

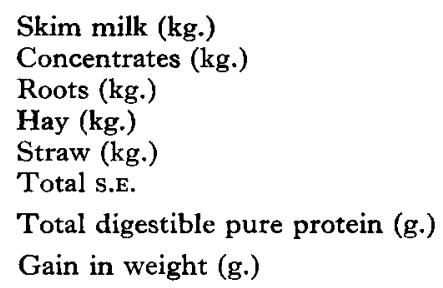

$\begin{array}{ccc}\text { Group (B) } & \text { Group (A) } & \text { Group (C) } \\ 0 & 0 & \mathrm{I} \cdot 0 \\ 0 \cdot 7 & \mathrm{I} \cdot \mathrm{I} & \mathrm{I} \cdot 0 \\ 15^{\circ} & 12 \cdot 0 & 12 \cdot 0 \\ 2 \cdot 1 & 2 \cdot \mathrm{I} & 2 \cdot \mathrm{I} \\ \mathrm{I} \cdot 8 & 2 \cdot \mathrm{I} & 2 \cdot \mathrm{I} \\ 3 \cdot 19 & 3 \cdot 19 & 3 \cdot 20 \\ 293 & 378 & 592 \\ 55 \mathrm{I} \pm 40^{*} & 631 \pm 29^{*} & 674 \pm 37^{*}\end{array}$

* Standard error of the mean.

At both ages about $300 \mathrm{~g}$. digestible pure protein was too little; nor does it seem that $380 \mathrm{~g}$. produced the greatest possible gain in weight, but the difference in gain between groups $(\mathrm{A})$ and $(\mathrm{C})$ is far from being statistically significant.

A similar statement can be made about the 18 months old heifers at the beginning 
of the winter period. The following table shows their daily consumption of fodder and gain in weight:

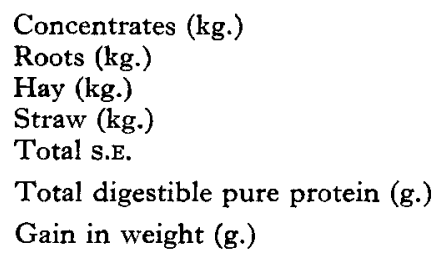

$\begin{array}{ccc}\text { Group (B) } & \text { Group (A) } & \text { Group (C) } \\ 0.2 & 0.5 & 0.8 \\ r 6 \cdot 0 & 13 \cdot 0 & 13^{\circ} \circ \\ 2 \cdot 5 & 2 \cdot 5 & 2 \cdot 4 \\ 2 \cdot 0 & 2 \cdot 0 & 2 \cdot 0 \\ 3.34 & 3 \cdot 21 & 3.30 \\ 283 & 340 & 500 \\ 499 \pm 46^{*} & 510 \pm 39^{*} & 537 \pm 49^{*}\end{array}$

* Standard error of the mean.

The differences in weight gain in this case were so slight that they may have been fortuitous. Just under $300 \mathrm{~g}$. digestible pure protein should thus be sufficient for heifers of this age.

\section{DISCUSSION}

If norms for the feeding of young stock are to be fixed on the basis of these experiments it must be emphasized that the energy requirements are to some extent dependent on the 'condition' in which it is desired to keep the animals. It is impossible to draw a hard and fast line between growth and fattening. It is advisable to choose a norm for the supply of energy which gives a satisfactory gain in weight and keeps the animals in medium condition.

In fixing norms for energy requirements it is usual to indicate the quantity either at a certain age or at a certain weight. The former method is applicable to certain breeds of cattle the normal size of which is well known; the latter method is often thought to be more universally valid, irrespective of breed. However, this is not the case; on the pontrary, an example from the experiments will show a drawback of this method. If we calculate how many s.E. were used daily $/ 1000 \mathrm{~kg}$. live weight we find:

\begin{tabular}{|c|c|c|c|}
\hline \multirow{2}{*}{$\begin{array}{c}\text { Age } \\
\text { (months) }\end{array}$} & \multicolumn{3}{|c|}{ Group } \\
\hline & (B) Lightly fed & (A) Normally fed & (C) Heavily fed \\
\hline $2-3$ & $12 \cdot 3$ & $17 \cdot 0$ & $18 \cdot 4$ \\
\hline $4^{-6}$ & 14.0 & 15.5 & $18 \cdot 6$ \\
\hline $7-9$ & $13 \cdot 2$ & $14 \cdot x$ & $15 \cdot 8$ \\
\hline $10-12$ & II. 3 & 12.5 & 14.1 \\
\hline $\begin{array}{l}13-15 \\
16-18\end{array}$ & $\begin{array}{r}10.2 \\
8.8\end{array}$ & $11 \cdot 6$ & 13.4 \\
\hline $\begin{array}{l}16-18 \\
19-21\end{array}$ & $\begin{array}{l}8 \cdot 8 \\
7 \cdot 8\end{array}$ & $\begin{array}{r}10 \cdot 0 \\
9 \cdot 5\end{array}$ & $\begin{array}{l}12 \cdot 3 \\
11 \cdot I\end{array}$ \\
\hline $22-24$ & $6 \cdot 7$ & $8 \cdot 5$ & 10.2 \\
\hline
\end{tabular}

After the age of 6 months there are only slight differences between the experimental groups. The reason for this is that the lightly fed group had been retarded in weight; the animals are too small for their age, and because of this the fodder becomes excessive in relation to their small size.

Heifers which are too small for their age, and whose feeding requirements are fixed in proportion to their weight, will be given too little, and they will still remain small; Frederiksen (1934) therefore proposed that a distinction should be made between maintenance food and production food in fixing the norms. The maintenance food 
should, as usual, be expressed in terms of the live weight according to the accepted formula:

$$
E=K V^{n} \text {, }
$$

where $E$ is the energy requirement, $K$ a constant for the species of animals in question, and $V$ the weight. The values used here are given on $\mathrm{p} .146$, and accordingly the daily maintenance requirement should be as follows:

$\begin{array}{cccccc}\begin{array}{c}\text { Weight } \\ \text { (kg.) }\end{array} & \begin{array}{c}\text { Maintenance } \\ \text { requirement } \\ \text { (s.E.) }\end{array} & \begin{array}{c}\text { Weight } \\ \text { (kg.) }\end{array} & \begin{array}{c}\text { Maintenance } \\ \text { requirement }\end{array} & \begin{array}{c}\text { Weight } \\ \text { (k.E.) }\end{array} & \begin{array}{c}\text { Maintenance } \\ \text { requirement } \\ \text { (s.E.) }\end{array} \\ 50 & 0.6 & 250 & 1 \cdot 7 & 450 & 2 \cdot 5 \\ 100 & 1 \cdot 0 & 300 & 1 \cdot 9 & 500 & 2 \cdot 7 \\ 150 & 1 \cdot 3 & 350 & 2 \cdot 1 & 550 & 2 \cdot 8 \\ 200 & 1 \cdot 5 & 400 & 2 \cdot 3 & 600 & 3 \cdot 0\end{array}$

The production food is estimated in relation to the expected final weight of the breed or the animal in question. In the Red Danish Milk breed the final weight may be estimated at $550 \mathrm{~kg}$., but a much more exact specification may be used, e.g. the average of the final weight of the mother and of the paternal grandmother which in most cases may be presumed to be known. Suppose the mother weighed $500 \mathrm{~kg}$. as a fully developed cow, and the paternal grandmother $580 \mathrm{~kg}$.; one may then anticipate a weight of about $540 \mathrm{~kg}$. as the final weight for the calf in question and fix the production fodder accordingly. This is expressed as a certain percentage of the final weight, and on the basis of this experiment the following is proposed:

\section{Light feeding Normal feeding Heavy feeding}

s.E. for production, daily $0 \cdot 10-0 \cdot 15 \%$ of the final weight in $\mathrm{kg}$. $0.15-0.20 \%$ of the final weight in $\mathrm{kg}$. $0.20-0.30 \%$ of the final weight in $\mathrm{kg}$.

The following percentages were used in the experiments, where the final weight was estimated at $550 \mathrm{~kg}$. S.E. as $\%$ of the final weight in $\mathrm{kg}$., daily

Age
(months)
$2 \frac{1}{2}-4 \frac{1}{2}$
$4 \frac{1}{2}-6 \frac{1}{2}$
$7 \frac{1}{2}-9 \frac{1}{2}$
$10 \frac{1}{2}-12 \frac{1}{2}$
$14 \frac{1}{2}-16 \frac{1}{2}$
$17 \frac{1}{2}-19 \frac{1}{2}$

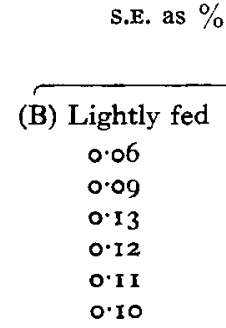

Group

The so-called normally fed group was heavily fed from the time when the animals were 7 or 8 months old, which corresponds to the condition of the animals at that age. The heavily fed group was fed very heavily, as shown by the condition of the animals; they were already rather fat from the age of 6 months onwards.

If it is desired to calculate the daily feeding requirements for a Shorthorn heifer of $250 \mathrm{~kg}$. (about I year old) and of a final weight of $650 \mathrm{~kg}$., this is done as follows:

$\left.\begin{array}{l}\text { For maintenance } I \cdot 7 \text { S.E. } \\ \text { For production } \frac{650 \times 0 \cdot I 75}{I O 0}=I \cdot I \text { S.E. }\end{array}\right\} 2 \cdot 8$ S.E. in all. 
For a Jersey heifer of $200 \mathrm{~kg}$. (also about I year old) and of a final weight of $400 \mathrm{~kg}$. the daily requirements should be:

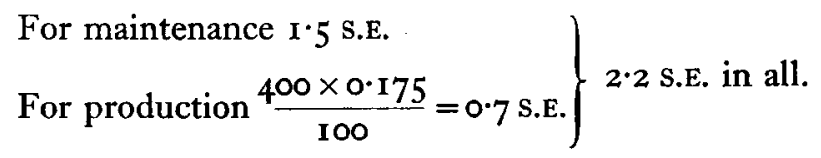

Norms for the protein requirement may be fixed either in proportion to the age, size, or S.E. requirement of the animals. Provided that the last quantity is fixed fairly exactly, it will, according to Møllgaard's (I94I $a$ ) theory, be most correct to express the protein requirement as digestible pure protein/S.E. Using as a basis the abovementioned experiments, we find the following norms, derived from the quantities consumed by group (B) in Exp. Ka.4 and group (A) in Exp. Ka.6, which are considered sufficient:

$\begin{array}{cccccc}\begin{array}{c}\text { Age } \\ \text { (month) }\end{array} & \begin{array}{c}\text { Digestible } \\ \text { pure protein } \\ \text { (g./day) }\end{array} & \begin{array}{c}\text { Digestible } \\ \text { pure protein } \\ \text { (g./s.e.) }\end{array} & \begin{array}{c}\text { Age } \\ \text { (month) }\end{array} & \begin{array}{c}\text { Digestible } \\ \text { pure protein } \\ \text { (g./day) }\end{array} & \begin{array}{c}\text { Digestible } \\ \text { pure protein } \\ \text { (g./s.E.) }\end{array} \\ \mathbf{1}-2 & 250 & 180 & 6-9 & 375 & 165 \\ 2-3 & 300 & 195 & 9-12 & 375 & 150 \\ 3-4 & 325 & 195 & 12-15 & 375 & \text { 135 } \\ 4-5 & 350 & 195 & 15-18 & 350 & \text { 20 } \\ 5-6 & 375 & 195 & 18-24 & 325 & \text { I05 } \\ & & & \text { Over 24 } & 325-475 & \text { 100-I15 }\end{array}$

Accordingly, the Shorthorn and the Jersey heifers should have daily $2.8 \times 15^{0}=420$ and $2 \cdot 2 \times 150=330 \mathrm{~g}$. digestible pure protein, respectively.

In Scandinavian as well as in British dairy cattle breeds there are many cows which average $55^{\circ} \mathrm{kg}$. live weight; the norms for these animals during their first 2 years will be as follows:

$\begin{array}{ccc}\begin{array}{c}\text { Age } \\ \text { (months) }\end{array} & \text { S.E./day } & \begin{array}{c}\text { Digestible } \\ \text { pure protein } \\ \text { (g./day) }\end{array} \\ \text { I-2 } & 1 \cdot 6 & 290 \\ 2-3 & 1 \cdot 8 & 350 \\ 3-4 & 1 \cdot 9 & 370 \\ 4-5 & 2 \cdot 0 & 390 \\ 5-6 & 2 \cdot 1 & 410 \\ 6-9 & 2 \cdot 4 & 395 \\ 9-12 & 2 \cdot 6 & 390 \\ 12-15 & 2 \cdot 8 & 375 \\ 15-18 & 3 \cdot 0 & 360 \\ \text { I } 8-24 & 3 \cdot 2 & 335 \\ \text { Above 24 } & 3 \cdot 5 & 350-400\end{array}$

It may be justifiable to deviate from this norm after the age of 9 months, but to utilize the strong growth potential of quite young animals, calves below that age should not be given less.

With heifers about I year old, and with older heifers, it will be economically correct, when making plans for winter feeding, to consider the condition of the summer feeding. If there is good pasture for the heifers it will be justifiable to reduce the quantities quoted, that is, to carry out light feeding during the winter. 
Besides, it will be justifiable to reduce the fodder somewhat if the heifers calve later than normally, that is, if calving is required in a certain season, e.g. in autumn. Under Danish conditions, the first calving is generally desired at an age of $2 \frac{1}{4}-2 \frac{1}{2}$ years. Calves born in autumn will themselves calve in spring, if they are to calve at the above ages; if it is necessary that the first calving should take place in the autumn, the calving must be postponed for 6 months. The last winter before calving, that is, when the heifers are about $2-2 \frac{1}{2}$ years old, they may well be fed on a reduced norm; a reduction of $25 \%$ will in this case be quite justifiable.

The old saying, 'The master's eye fattens the ox', is true to a certain extent, as by watching the animals it is possible to obtain some information about the fodder supply which may be insufficient or abundant; but it is also equally true that the safest guide is obtained from experiments which give the most exact information about the quantity and composition of the fodder and the gains in weight.

\section{SUMMARY}

I. The amounts of starch equivalent (S.E.) and protein necessary for growing dairy heifers were examined in a series of experiments with animals of the three breeds common in Denmark, the Red Danish Milk, the Black and White Jutland, and the Dairy Shorthorn. The experiments extended from the age of 16 days until the first calving, which generally takes place at the age of 27 months.

2. Considerable variations in the level of feeding young stock are reflected in pronounced differences in growth, live weight and body size of the animals. Between the three breeds there is only a slight difference in growth.

3. The effect of a low level of feeding during the winter period may to a large degree be counterbalanced by good pasture in the succeeding summer season. After 9 months of age, the animals can subsist entirely on pasture in the summer.

4. The differences in live weight and development at first calving, resulting from a difference in the plane of nutrition, tend to disappear in the course of the first two lactation periods, when the cows are fed according to the standards adopted in Denmark. A considerable part of the gain is made on pasture.

5. The feed consumption $/ \mathrm{kg}$. gain in weight increases greatly with increasing age, whether total S.E. or production S.E. is used in the calculation. There was little difference in the consumption of total S.E. between groups of the same age, while the consumption of production S.E. was much greater for heavily fed than for normally fed animals.

6. A daily allowance of $300 \mathrm{~g}$. digestible pure protein was insufficient for normal growth in these animals. With $375-400 \mathrm{~g}$. nearly normal gains in weight were obtained.

7. A new method for calculating the s.E. requirement has been worked out according to Lars Frederiksen's proposal. On this basis, norms for S.E. and for protein requirements are suggested for growing young stock of breeds in which the fully developed cows weigh $55^{\circ} \mathrm{kg}$. 


\section{REFERENCES}

Brüggemann, $H$. (1938). Tierernährung, so, 296.

Eckles, C. H. \& Swett, W. W. (1918). Res. Bull. Mo. agric. Exp. Sta. no. 3 I.

Eskedal, H. W. \& Steensberg, V. (I931). Beretn. Forsøgslab. Kbh. no. 142.

Espe, D. L., Cannon, C. Y. \& Hansen, E. N. (1932). Res. Bull. Ia agric. Exp. Sta. no. 154.

Frederiksen, L. (1929). Beretn. nordisk LandbrKongr. 4, 67.

Frederiksen, L. (1930). Tabeller og Tavler til Beregning af Malkekoens Foder, 3rd ed. København: Ejvind Christensen.

Frederiksen, L. (1934). Beretn. dansk. Landboforen., Aarhus, p. 146.

Frederiksen, L. \& Østergaard, P. S. (1931). Beretn. Forsogslab. Kbh. no. 136.

Hammond, J. (1944). Pamphl. Bath W.S. Co. Soc. no. 12.

Isaachsen, H. \& Ulvesli, O. (1929). Norg. Landbrukshøisk. Beretn. ForForsøk. no. 23.

Jääskeläinen, O. (1936). Suom. Maataloust. Seur. Fulk. 33, r.

Møllgaard, H. (1941 a). Laerebog i Grundtraekkene af Husdyrenes Ernearingsfysiologi, 3rd ed., p. 353. København: Nyt nordisk Forlag.

Møllgaard, H. (194I b). Laerebog $i$ Grundtraekkene af Husdyrenes Ernearingsfysiologi, 3rd ed., p. 370. København: Nyt nordisk Forlag.

Østergaard, P. S. (1934). Beretn. Forsøgslab. Kbh. no. 156.

Schmidt, J. \& Vogel, H. (1929). Z. Zücht. B, r9, 373.

Schmidt, J. \& Vogel, H. (1933). Z. Zücht. B, 26, 145.

Steensberg, V. (1935). Beretn. nordisk LandbrKongr. 5, 663.

Steensberg, V. (1940). Beretn. Forsøgslab. Kbh. no. 189.

Steensberg, V. (1947). Beretn. Forsøgslab. Kbh. no. 227.

Steensberg, V. \& Østergaard, P. S. (1945). Beretn. Forsogslab. Kbh. no. 216.

Waters, H. J. (1908). Paper read at 29th Annual Meeting of the Society for the Promotion of Agriculture Science.

Zorn, W., Krallinger, H. F., Schneider, K. T. \& Schott, A. (1933). Arch. Tierernähr. Tierz. 9, I94. 